- Eiichi Maruyama, the former Hitachi research manager who heads the MITI Ångstrom Technology Partnership. That is why, Maruyama claims, companies welcome MITI's initiative.

Some Japanese researchers, however, are concerned about the large amounts of government funding going into the field. "The presence of so many projects is not a good sign," says Hiroyuki Sakaki. "Particularly for younger researchers, it may be more intelligent to look for some newer subject one that will attract people in ten years' time."

Bob Johnstone

\section{Latin America pleads for more technology}

São Paulo. The heads of state and government of Latin American and Caribbean countries last week issued a joint plea to industrialized countries not to impose obstacles on the transfer of the technologies they need to modernize their economies and adjust to the pressures of international competition.

They also said, in addition to more access to Western technologies, they would like to participate in the development of new technology as "producers and consumers" of knowledge. But, although discussing the prospects for greater regional cooperation in science and technology, no new measures were agreed to. The only concrete result of such diplomatic promises is an Argentinian-Brazilian biotechnology centre created in the $1980 \mathrm{~s}$.

The heads of state were in Rio de Janeiro for the eighth meeting of the so-called Rio Group, and will present a document listing their conclusions to the American Summit in Miami next December. Among other things, the document says that "national and international controls for the transfer of dual technologies [those with both civilian and military applications] should not hinder the access to goods and advanced technologies of pacific use with the aim of development".

The heads of state point out that their region was the first to commit itself, through the Treaty of Tlatelolco, to remaining free of nuclear and other weapons of mass destruction. But the document is not intended to refer only to the uses of nuclear energy. Brazil, for example, feels that it has been treated unfairly over its Satellite Vehicle Launcher, which the United States fears may be converted into a ballistic missile.

A boycott by Western nations has meant that Brazil has turned to China for help with the development of satellites. And last week (15 September) Brazil signed a nuclear energy agreement with Russia that may lead to Russian assistance for Brazilian reactors.

Ricardo Bonalume Neto

The former head of India's Atomic Energy Commission, M. R. Sirinivana, last week claimed that India possessed nuclear weapons, which were being kept as a "protection" against Pakistan.

\title{
Pasteur Institute climbs out of rags and into riches
}

Paris. Next year, the centenary of the death of Louis Pasteur, has been designated the "year of Pasteur" by UNESCO. It comes just as an internal review of the activities of the Pasteur Institute in Paris shows remarkable growth over the past six years, due mainly to large increases in its income from patents and commercial services, and legacies and donations.

Both trends would have pleased Pasteur himself, who considered applied and fundamental research as equally important, "linked as a fruit to its tree". Pasteur also began the institute's tradition of fund raising; it was founded in 1887 with FFr 2 million - around FFr50 million (US\$9.4 million) at today's values - raised in this way.

The institute's budget has grown from FFr550 million in 1988 to FFr860 million last year a growth of 55 per cent in five years. According to the review, income from industry grew from FFr70 million to FFr160 million over this period, and from commercial services such as the preparation of monoclonal antibodies from FFr53 million to FFr 70 million. As a result, their combined share of the total budget has increased from 20.5 to 26 per cent.

Legacies and donations, the Pasteur's other traditional source of income, increased from 18.8 to 27.2 per cent of the total budget. Legacies alone accounted for FFr190 million in 1993; one donor, the British company Virgin, raised FFr12 million for AIDS research at the institute through the sale of a compact disc recorded by a number of prominent singers.

As a result of the growth in Pasteur's own resources, even though government funding increased by 10 per cent between 1988 and 1993, its share of the total budget has dropped from 47 to 36 per cent. The new figures therefore represent a turnaround in Pasteur's long struggle to generate income and regain some of the independence it lost in 1965 when a financial crisis forced it to turn to the state for support.

At the time, Général Charles De Gaulle, the then French president, did not hesitate to help an institute that he once called "as untouchable as the Eiffel Tower". But his government made its support conditional on Pasteur separating its research from its commercial and industrial activities.

Pasteur's subsequent transition from a cottage industry into a one responsible for joint ventures with international companies has not been easy. In 1972, for example, it created Institut Pasteur Production (IPP). Sanofi, a subsidiary of the French oil company Elf, took a 35 per cent stake in IPP in 1976, but the company was still losing money in 1984 . Profitability came only after Pasteur handed over control of its vaccines and serums business to Institut Mérieux (a subsidiary of the Rhône-Poulenc group), and of its diagnostics business to Sanofi.

Pasteur-Mérieux Vaccines and Serums is now the world leader in the \$2-billion vaccine market, with three-quarters of its sales outside France (last year the company distributed a billion doses of vaccines). Pasteur-Sanofi Diagnostics ranks fifteenth in the world market, with sales of FFr1.4 billion last year.

Much of Pasteur's recent success has come from its aggressive patenting policy. Income has tripled since 1988 and risen from 9 to 18 per cent of the total budget. The institute now has 254 patents, and gives a

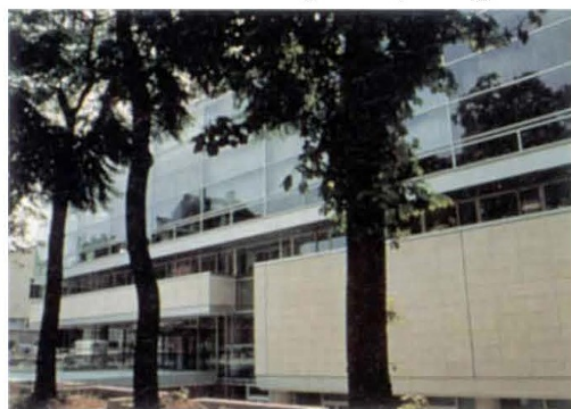

The new FF 110 million scientific information centre which is being opened at the Institut Pasteur in Paris next week by Edoaurd Balladur, the French prime minister. Financed from a FFr270 million legacy of jewels from the Duchess of Windsor, the centre will hold the 30,000 books and volumes of 2,500 journals of the existing library, one of the finest collections in microbiology.

share of royalties to individual researchers, although it recently fixed an annual ceiling of FFr300,000 to prevent some researchers earning too much more than others.

All of these results have come as a boost to the standing of Maxine Schwartz, who was reelected earlier this year as director of the institute for a second six-year term. The internal review covered his first term of office, and during this period the institute also expanded and reoriented its research activities.

Concrete evidence of this growth includes a large new building for research on AIDS and retroviruses, the most visible evidence of the institute's massive investment in an area that involves a tenth of its researchers and its budget. Next week will see the opening of a FFr110-million hightechnology scientific information centre which symbolizes the institute's desire to increase its attractiveness to both French and foreign scientists.

Declan Butler 